\title{
Phosphatidylcholine bilayers trigger the degradation of licofelone
}

\author{
As bicamadas de fosfatidilcolina induzem a degradação do licofelone
}

\author{
Catarina Pereira-Leite ${ }^{1,2, a}$, Cláudia Nunes ${ }^{1}$, Iolanda M. Cuccovia ${ }^{2}$, Salette Reis ${ }^{1}$
}

${ }^{1}$ LAQV, REQUIMTE, Departamento de Ciências Químicas, Faculdade de Farmácia, Universidade do Porto, Rua de Jorge Viterbo Ferreira 228, 4050-313 Porto, Portugal

${ }^{2}$ Departamento de Bioquímica, Instituto de Química, Universidade de São Paulo, Av. Prof. Lineu Prestes 748, 05508-000 São Paulo, SP, Brazil

${ }^{a}$ current affiliation: CBIOS, Universidade Lusófona's Research Center for Biosciences and Health Technologies, Campo Grande 376, 1749-024 Lisboa, Portugal

E-mail: catarina.leite@ulusofona.pt, ${ }^{\text {a }}$ current affiliation address

\begin{abstract}
This is the first report, to the best of our knowledge, on the degradation of licofelone, a dual cyclooxygenaselipoxygenase inhibitor under development, in phosphatidylcholine bilayers. With the objective of characterizing licofelone-phosphatidylcholine interactions to understand its better gastric tolerability over conventional nonsteroidal anti-inflammatory drugs, our preliminary data showed that the lower the $\mathrm{pH}$, the higher the rate and extent of licofelone degradation in the presence of phosphatidylcholine liposomes. The lipid concentration was another critical factor influencing the rate and extent of licofelone degradation, suggesting that phosphatidylcholine bilayers may act as a catalyst. These data highlight the need of considering lipids in drug development to better predict the drug pharmacokinetics prior to clinical evaluation.
\end{abstract}

Keywords: Anti-inflammatory drugs, dual COX-LOX inhibitors, liposomes, UV-Vis spectrophotometry

\section{Resumo}

Este trabalho demonstra pela primeira vez, segundo julgamos saber, a degradação do licofelone, um inibidor duplo da cicloxigenase e da lipoxigenase em desenvolvimento, em bicamadas de fosfatidilcolina. Com o objetivo de caracterizar as interações do licofelone com a fosfatidilcolina para melhor entender a sua melhor tolerabilidade gástrica em relação aos anti-inflamatórios não esteroides convencionais, os resultados preliminares obtidos demonstraram que quanto menor o $\mathrm{pH}$, maior a velocidade e a extensão da degradação do licofelone na presença de lipossomas de fosfatidilcolina. A concentração lipídica foi outro fator determinante quanto à velocidade e a extensão da degradação deste fármaco, sugerindo que as bicamadas de fosfatidilcolina poderão atuar como um catalisador. Estes resultados destacam a necessidade de considerar os lípidos durante o desenvolvimento de novos fármacos para melhor predizer as suas propriedades farmacocinéticas antes da avaliação clínica.

Palavras-chave: Medicamentos anti-inflamatórios, inibidores duplos COX-LOX, lipossomas, espectrofotometria UV-Vis 


\section{Introduction}

Licofelone (Figure 1) is a drug under development, considered as one of the most promising dual inhibitors of cyclooxygenase (COX) and 5-lipoxygenase (5LOX). This compound was developed as alternative to nonsteroidal anti-inflammatory drugs (NSAIDs) to improve their safety profile through the additional inhibition of 5-LOX (1). According to cell-based studies and animal tests, licofelone is a potent inhibitor of COX-1, microsomal prostaglandin E2 synthase-1 (mPGES-1), and 5-LOX, reducing the eicosanoid biosynthesis from both pathways. The drug directly inhibits COX-1 and mPGES-1 but it causes the reduction of 5-LOX products by interfering with FLAP (the 5-LOX activating protein) (2-4). The additional inhibition of 5-LOX is an important advantage of licofelone in comparison to NSAIDs, as it causes the reduction of $\mathrm{LTB}_{4}$ and cysteinyl-leukotrienes (CysLTs) levels, which are important mediators of leukoattraction and broncho- and vasocontriction (respectively). High levels of these leukotrienes, which are observed upon NSAIDs administration, play an important role in the gastrointestinal (GI) toxicity induced by nonselective NSAIDs. $(1,5)$ Thus, the dual inhibition of COX and 5-LOX cascade may maintain the efficacy and improve the tolerability of this anti-inflammatory therapy.

\section{Introdução}

O licofelone (Figura 1) é um fármaco em desenvolvimento muito promissor na categoria dos inibidores duplos da cicloxigenase (COX) e da 5-lipoxigenase (5LOX). Este composto foi desenvolvido para ser uma alternativa mais segura aos anti-inflamatórios não esteroides (AINEs), conseguida através da inibição adicional da 5-LOX (1). De acordo com estudos celulares e testes animais, o licofelone é um inibidor potente da COX-1, da sintetase microssomal da prostaglandina $\mathrm{E}$ (mPGES-1) e da 5-LOX, causando a redução da biossíntese de eicosanoides provenientes das duas vias (24). A inibição adicional da 5-LOX é uma vantagem importante do licofelone em comparação com os AINEs, já que causa a redução dos níveis de $\mathrm{LTB}_{4}$ e dos cisteinil-leucotrienos, os quais são importantes mediadores da atração leucocitária e da bronco e vasoconstrição (respetivamente). Elevados níveis destes leucotrienos são induzidos pela administração de AINEs e desempenham um papel importante na ocorrência de toxicidade gastrointestinal (GI) causada pelos AINEs não seletivos $(1,5)$. Assim sendo, é provável que a inibição dupla da COX e da 5-LOX possam manter a eficácia e melhorar a segurança da terapia anti-inflamatória.

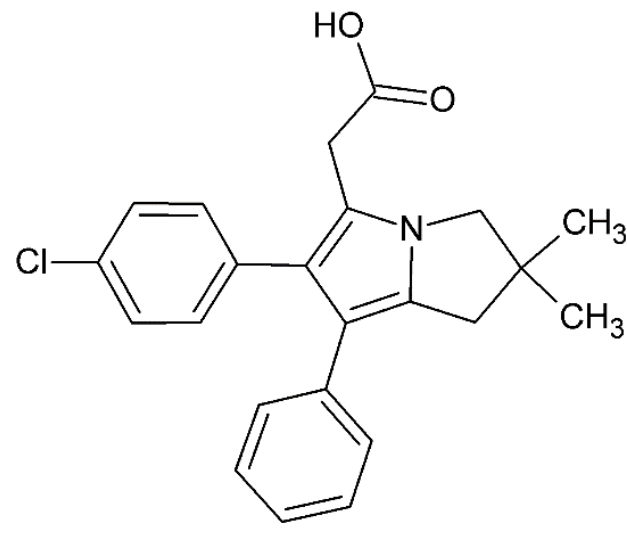

Figure 1/ Figura 1 - Structural formula of licofelone/ Formula estrutural do licofelone. 
Preclinical and clinical studies have been supporting such hypothesis. Animal studies have proven licofelone efficacy as an anti-inflammatory, analgesic, antipyretic, antiplatelet, antiasthmatic, and antiarthritic agent $(1,6)$. Preclinical studies have also indicated that licofelone is better tolerated in the GI tract and cardiovascular (CV) system than NSAIDs (7-9). Thus, licofelone has entered clinical trials for the treatment of osteoarthritis. Phase II and III published data suggested that licofelone is at least as effective as commercial NSAIDs, with an improved GI and CV safety profile $(1,10)$. Despite such favorable results, licofelone has not yet entered the market.

Various studies have been demonstrated that the gastric toxicity of nonselective NSAIDs may be related to their actions on the protective phospholipid layers of the gastric mucosa, particularly by the alteration of their biophysical properties (11-14). Thus, the objective of this work is to study the licofelone interactions with phospholipid bilayers to better understand its improved gastric tolerability. 1,2-Dimyristoyl-sn-glycero3-phosphocholine (DMPC) liposomes were used as model systems, since phosphatidylcholine is the main phospholipid of the human gastric mucosa (15) and it is in the fluid phase at physiological temperature $\left(37^{\circ} \mathrm{C}\right)$, as most phospholipids found in vivo. Moreover, the $\mathrm{pH}$ gradient found in the gastric mucosa, from the gastric lumen ( $\mathrm{pH} \sim 2)$ to the epithelial cells ( $\mathrm{pH} \sim 7)(16)$, was also considered. Thus, experiments were designed to be performed at $\mathrm{pH} 3.0,5.0$, and 7.4 to clarify the impact of media $\mathrm{pH}$ on licofelone-DMPC interactions.

Material and Methods

\section{Materials}

Licofelone [Cayman Chemical (Ann Arbor, MI)]; 1,2-dimyristoyl-sn-glycero-3-phosphocholine (DMPC) [Avanti Polar Lipids, Inc. (Alabaster, AL)]; dimethyl sulfoxide (DMSO), Trizma ${ }^{\circledR}$ base, acetic acid [Sigma-Aldrich Co. (St. Louis, MO)]; formic acid [Merck \& Co. (Kenilworth, NJ)]; methanol and chloroform [VWR International S.A.S. (Fontenais-sous-Bois, France)] were analytical grade or higher and used without further purification.

Formic acid, acetic acid, or Trizma ${ }^{\circledR}$ base were dis-
De facto, ensaios pré-clínicos e clínicos têm suportado a hipótese supracitada. Estudos em animais demonstraram a eficácia do licofelone como agente anti-inflamatório, analgésico, antipirético, antiagregante plaquetário, antiasmático e antiartrítico $(1,6)$. Estudos pré-clínicos também indicaram que o licofelone é melhor tolerado no trato GI e no sistema cardiovascular (CV) que os AINEs (7-9). Com base nestes resultados, o licofelone entrou em ensaios clínicos para o tratamento da osteoartrite. Os escassos dados que foram publicados quanto à fase II e III destes ensaios clínicos sugeriam que o licofelone é pelo menos tão eficaz como os AINEs, mas com um perfil de segurança GI e CV superior $(1,10)$. Apesar destes resultados favoráveis, o licofelone não foi comercializado até ao momento.

Tem vindo a ser demonstrado em vários estudos científicos que a toxicidade gástrica induzida pelos AINEs não seletivos está relacionada com os efeitos destes fármacos nas camadas protetoras de fosfolípidos da mucosa gástrica, particularmente através da alteração das propriedades biofísicas destas camadas (11-14). Neste sentido, neste estudo pretende-se estudar as interações do licofelone com bicamadas fosfolipídicas para clarificar os mecanismos inerentes à sua melhor tolerabilidade gástrica. Lipossomas constituídos por 1,2-dimiristoil-sn-glicero-3-fosfatidilcolina (DMPC) foram utilizados como sistemas miméticos, já que a fosfatidilcolina é o fosfolípido mais abundante da mucosa gástrica humana (15) e, tal como a maioria dos fosfolípidos encontrados in vivo, está na fase fluida à temperatura fisiológica (37 $\left.{ }^{\circ} \mathrm{C}\right)$. $\mathrm{O}$ gradiente de $\mathrm{pH}$ existente na mucosa gástrica, desde o lúmen gástrico $(\mathrm{pH} \sim 2)$ até às células epiteliais ( $\mathrm{pH} ~ 7)(16)$, também foi considerado, já que as experiências foram desenhadas para avaliar a interação licofelone-DMPC a pH 3,0, 5,0 e 7,4.

\section{Material e Métodos}

\section{Materiais}

Licofelone [Cayman Chemical (Ann Arbor, MI)]; 1,2-dimiristoil-sn-glicero-3-fosfatidilcolina (DMPC) [Avanti Polar Lipids, Inc. (Alabaster, AL)]; dimetil sulfóxido (DMSO), Trizma ${ }^{\circledR}$ base, ácido acético [Sigma-Aldrich Co. (St. Louis, MO)]; ácido fórmico [Merck \& Co. (Kenilworth, NJ)]; metanol e clorofórmio [VWR International S.A.S. (Fontenais-sous-Bois, France)] foram obtidos pelo menos com pureza analítica e foram usados sem processos de purificação adicionais.

$\mathrm{O}$ ácido fórmico, o ácido acético ou o Trizma ${ }^{\circledR}$ base 
solved in Milli-Q water to prepare formate $(10 \mathrm{mM}, \mathrm{pH}$ $3.0)$, acetate (10 mM, pH 5.0), or Tris $\mathrm{HCl}(10 \mathrm{mM}, \mathrm{pH}$ 7.4) buffer. The $\mathrm{pH}$ of buffered solutions was adjusted with $\mathrm{NaOH}$ or $\mathrm{HCl}$ solutions $(1 \mathrm{M})$.

\section{Preparation of liposomes}

Large unilamellar vesicles (LUVs) of DMPC were prepared by the lipid film hydration method followed by extrusion. Briefly, a lipid film was formed by evaporating the organic solvents to dryness, which was then hydrated with the appropriate buffer to yield multilamellar vesicles (MLVs). LUVs of DMPC were finally obtained by the extrusion of the previously obtained MLVs. Procedural details have been previously published (13).

\section{Kinetic studies by UV-Vis spectrophotometry}

The stability of licofelone was evaluated by temperature-controlled UV-Vis spectrophotometry. Increasing concentrations of DMPC LUVs $(0-1,000 \mu \mathrm{M})$ were tested at $\mathrm{pH} 3.0,5.0$, and 7.4. An aliquot of a stock solution of licofelone in DMSO was added to a cuvette filled with buffered DMPC LUVs at $37.0( \pm 0.5){ }^{\circ} \mathrm{C}$ and time was started. The temperature of the experiment was kept constant by using a thermostatted cell holder coupled with a circulating water bath. The final licofelone concentration and the final amount of DMSO were $15 \mu \mathrm{M}$ and $1 \%(\mathrm{v} / \mathrm{v})$ in all cases, respectively. Absorption spectra $(220-400 \mathrm{~nm})$ were acquired at 37.0 $( \pm 0.5){ }^{\circ} \mathrm{C}$ under magnetic stirring at different time intervals in a UV/Vis spectrophotometer (Jasco V-660).

\section{Prediction of $p K_{a}$ and $\log D$ values}

The acidity dissociation constant $\left(p K_{a}\right)$ and the octanol:water $\log D\left(\log D_{\mathrm{O} / \mathrm{w}}\right)$ of licofelone were predicted using MarvinSketch calculator from Chemaxon. The $p K_{a}$ value was calculated using the $p K_{a}$ plugin while the $\log \mathrm{D}$ plugin considering the consensus method was used to determine the $\log D_{\mathrm{O} / \mathrm{W}}$ of licofelone at $\mathrm{pH} 3.0$, 5.0, and 7.4.

\section{Results}

The study of licofelone-DMPC interactions was initiated by the determination of the drug partition coefficient between the buffered medium and the lipid phase by derivative spectrophotometry. This experiment consists of acquiring the absorption spectra of licofelone with increasing concentrations of DMPC liposomes after an foram dissolvidos em água Milli-Q para preparar as soluções tampão de formato $(10 \mathrm{mM}, \mathrm{pH} 3,0)$, acetato $(10 \mathrm{mM}, \mathrm{pH} 5,0)$ ou Tris $\mathrm{HCl}(10 \mathrm{mM}, \mathrm{pH} 7,4) . \mathrm{O} \mathrm{pH}$ destes tampões foi ajustado com soluções de $\mathrm{NaOH}$ ou $\mathrm{HCl}(1 \mathrm{M})$.

\section{Preparação de lipossomas}

Vesículas unilamelares grandes (LUVs) de DMPC foram preparadas através do método de hidratação do filme lipídico seguido de extrusão. Sucintamente, preparou-se um filme lipídico através da evaporação de solventes orgânicos, o qual foi posteriormente hidratado com o tampão apropriado para se obterem vesículas multilamelares (MLVs). Os LUVs de DMPC foram finalmente obtidos pela extrusão da suspensão de MLVs. Os detalhes deste procedimento foram previamente publicados (13).

\section{Estudos cinéticos por espectrofotometria UV-Vis}

A estabilidade do licofelone foi avaliada por medidas de espectrofotometria UV/Vis realizadas a temperatura controlada. Concentrações crescentes de LUVs de DMPC $(0-1000 \mu \mathrm{M})$ foram testadas a pH 3,0, 5,0 e 7,4. Uma alíquota de uma solução de licofelone em DMSO foi adicionada à cuvete contendo LUVs de DMPC a $37.0( \pm 0.5){ }^{\circ} \mathrm{C}$ e o registo do tempo foi iniciado. Ao longo da experiência, a temperatura foi controlada pelo recurso a um suporte de cuvete termostatizado através da circulação de água aquecida. A concentração de licofelone testada foi $15 \mu \mathrm{M}$ e a quantidade de DMSO foi $1 \%(\mathrm{v} / \mathrm{v})$ em todos os casos. Espectros de absorção $(220$ - $400 \mathrm{~nm})$ foram recolhidos a $37.0( \pm 0.5)^{\circ} \mathrm{C}$ com agitação magnética em diferentes intervalos de tempo, usando um espectrofotómetro UV/Vis (Jasco V-660).

Determinação dos valores de $p K_{a}$ e $\log D$

A constante de dissociação ácida $\left(p K_{a}\right)$ e o $\log D$ octanol:água $\left(\log D_{\mathrm{O} / \mathrm{A}}\right)$ do licofelone foram determinados pelo recurso ao programa MarvinSketch calculator da Chemaxon. $\mathrm{O}$ valor de $p K_{a}$ foi calculado utilizando o $p K_{a}$ plugin. Já o $\log D$ plugin considerando o método consensos foi utilizado para determinado o $\log D_{\mathrm{O} / \mathrm{A}}$ do licofelone a $\mathrm{pH}$ 3,0, 5,0 e 7,4.

\section{Resultados}

O estudo das interações licofelone-DMPC iniciou-se pela determinação do coeficiente de partilha do fármaco entre o meio aquoso e a fase lipídica por espectrofotometria derivativa. Esta experiência consiste em adquirir os espectros de absorção do licofelone na presença de concentrações crescentes de lipossomas de DMPC após 
incubation period $(13,17)$. Remarkable differences in the licofelone spectrum for the same DMPC concentrations at $\mathrm{pH} 7.4$ or at $\mathrm{pH} 3.0$ caught our attention and hampered the completion of the partition coefficient study. Thus, the licofelone stability was evaluated over time (0 to $150 \mathrm{~min})$ at $\mathrm{pH} 3.0$ in the presence of the smallest DMPC concentration $(100 \mu \mathrm{M})$ used in derivative spectrophotometry experiments (Figure 2A). Licofelone was not stable at $\mathrm{pH} 3.0$ in the presence of DMPC liposomes, since the well-defined absorption peaks of licofelone at 249 and $281 \mathrm{~nm}$ decreased in intensity and a new absorption band appeared around 325 $\mathrm{nm}$ over time (arrows, Figure 2A). The same spectral alterations were observed when other DMPC concentrations were tested $(200,500$, and 1,000 $\mu \mathrm{M})$. However, the absorbance variation at 281 and $325 \mathrm{~nm}$, expressed as $A_{0} / A-1$, where $A_{0}$ is the initial absorbance of licofelone ( $\mathrm{t}=0 \mathrm{~min})$, was dependent on the DMPC concentration (Figure 2B). As DMPC concentration increased, the spectral alterations occurred later and to a lesser extent. um período de incubação $(13,17)$. Diferenças notáveis no espectro de absorção do licofelone, para as mesmas concentrações de DMPC a pH 7,4 ou pH 3,0, chamaram a nossa atenção e impediram a conclusão do estudo do coeficiente de partilha. Assim, a estabilidade do licofelone foi avaliada ao longo do tempo (0 a $150 \mathrm{~min}$ ) a $\mathrm{pH}$ 3,0 na presença da menor concentração de DMPC (100 $\mu \mathrm{M})$ usada nos ensaios de espectrofotometria derivativa (Figura 2A). A degradação do licofelone a pH 3,0 na presença de lipossomas de DMPC foi notória, já que os picos de absorção do licofelone (249 e $281 \mathrm{~nm}$ ) diminuíram de intensidade e uma nova banda de absorção apareceu a cerca de $325 \mathrm{~nm}$ ao longo do tempo (setas, Figura 2A). As mesmas alterações espectrais foram observadas quando outras concentrações de DMPC foram testadas $(200,500$ e $1000 \mu \mathrm{M})$. No entanto, a variação da absorvência a 281 e $325 \mathrm{~nm}$, expressa em $\mathrm{A}_{0} / \mathrm{A}-1$ em que $\mathrm{A}_{0}$ é a absorvência inicial de licofelone $(\mathrm{t}=0$ min), dependia da concentração de DMPC (Figura 2B). À medida que a concentração de DMPC aumentava, as alterações espectrais ocorreriam mais tarde e em menor extensão.
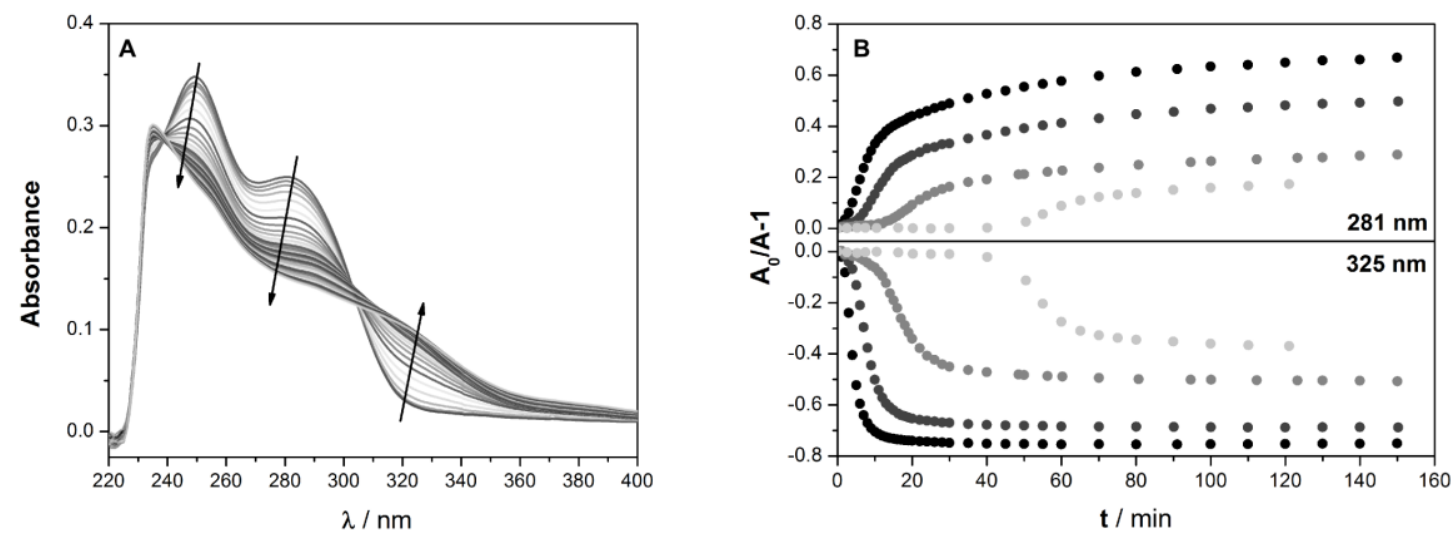

Figure 2/ Figura 2 - (A) Absorbance spectra of licofelone at $\mathrm{pH} 3.0$ in the presence of DMPC LUVs $(100 \mu \mathrm{M})$ as a function of time $(0-150 \mathrm{~min})$. Arrows highlight the main spectral alterations over time. (B) Licofelone absorbance variation, expressed as A0/A-1, at $281 \mathrm{~nm}$ (upper graph) and $325 \mathrm{~nm}$ (lower graph), at $\mathrm{pH} 3.0$ as a function of time and DMPC concentration [100 $\mu \mathrm{M}$ (black), $200 \mu \mathrm{M}$ (dark gray); $500 \mu \mathrm{M}$ (gray); $1000 \mu \mathrm{M}$ (light gray)]/ (A) Espectro de absorção do licofelone a pH 3,0 na presença de LUVs de DMPC $(100 \mu \mathrm{M})$ em função do tempo $(0$ - $150 \mathrm{~min})$. As setas realçam as alterações espectrais principais ao longo do tempo. (B) Variação da absorvência do licofelone, expressa como A0/A-1, a $281 \mathrm{~nm}$ (painel superior) e a $325 \mathrm{~nm}$ (painel inferior) a pH 3,0 em função do tempo e da concentração de DMPC [100 $\mu \mathrm{M}$ (preto), $200 \mu \mathrm{M}$ (cinzento escuro); 500 $\mu \mathrm{M}$ (cinzento); $1000 \mu \mathrm{M}$ (cinzento claro)]. 
Licofelone stability was similarly evaluated at $\mathrm{pH} 5.0$ and 7.4 (Figure 3). At pH 5.0, the bathochromic shift observed at $\mathrm{pH} 3.0$ over time was also verified (Figure $3 \mathrm{~A})$. It is notable that, for the same DMPC concentrations, the time-lag before spectral changes $\left(\mathrm{t}_{\text {lag }}\right)$ was longer at $\mathrm{pH} 5.0$ than at $\mathrm{pH} 3.0$. Moreover, the extent of licofelone degradation, expressed as the maximum variation of licofelone absorbance $\left[\left(\mathrm{A}_{0} / \mathrm{A}-1\right)_{\max }\right.$, was lower at $\mathrm{pH} 5.0$ than at $\mathrm{pH} 3.0$ (Figure 4B). Furthermore, the licofelone degradation was also dependent on the DMPC concentration, since $\mathrm{t}_{\mathrm{lag}}$ increased and $\left(\mathrm{A}_{0} / \mathrm{A}-1\right)$ max decreased by increasing DMPC concentration at $\mathrm{pH}$ 3.0 and 5.0 (Figure 4).

At $\mathrm{pH} 7.4$, no spectral alterations were observed for at least two hours with all DMPC concentrations tested (Figure 3B). It is noteworthy that licofelone degradation occurred within 30 minutes at $\mathrm{pH} 3.0$ (Figure 2B), while it was not observed for four hours at $\mathrm{pH} 7.4$ (Figure 3B) with the smallest DMPC concentration tested. Moreover, licofelone was stable in the absence of DMPC LUVs at pH 7.4 for 150 minutes. Due to solubility restrictions of licofelone in acidic media, the drug stability at pH 5.0 and 3.0 without liposomes could not be evaluated.
A estabilidade do licofelone foi avaliada de forma semelhante a pH 5,0 e 7,4. A pH 5,0 também se verificou o desvio batocrómico observado a pH 3,0 ao longo do tempo (Figura 3A). É importante ressaltar que, para as mesmas concentrações de DMPC, o intervalo de tempo decorrido antes das alterações espectrais se verificarem $\left(\mathrm{t}_{\mathrm{lag}}\right)$ foi superior a $\mathrm{pH}$ 5,0 do que a $\mathrm{pH}$ 3,0. Mais ainda, a extensão da degradação do licofelone, expressa como a variação máxima da absorvência do licofelone $\left[\left(\mathrm{A}_{0} / \mathrm{A}\right.\right.$ 1) $)_{\max }$ ], foi inferior a $\mathrm{pH} 5,0$ do que a $\mathrm{pH} \mathrm{3,0} \mathrm{(Figura}$ 4B). Além disso, a degradação do licofelone também foi dependente da concentração de DMPC, já que o $t_{\text {lag }}$ aumentou e $\left(\mathrm{A}_{0} / \mathrm{A}-1\right)_{\max }$ diminuiu à medida que a concentração de DMPC aumentou a pH 3,0 e 5,0 (Figura 4).

A pH 7,4 não foram observadas alterações espectrais durante pelo menos $2 \mathrm{~h}$ independentemente da concentração de DMPC testada (Figura 3B). É de notar que, para a menor concentração de DMPC testada, a degradação do licofelone ocorreu ao fim de $30 \mathrm{~min}$ a pH 3,0 (Figura 2B), mas não foi observada durante $4 \mathrm{~h}$ a pH 7,4 (Figura 3B). Além disso, não se verificou a degradação do licofelone na ausência de LUVs de DMPC a pH 7,4 durante $150 \mathrm{~min}$. Devido às restrições de solubilidade do licofelone em meio ácido, não foi possível avaliar a estabilidade do fármaco na ausência de lipossomas a $\mathrm{pH} 5,0$ e 3,0
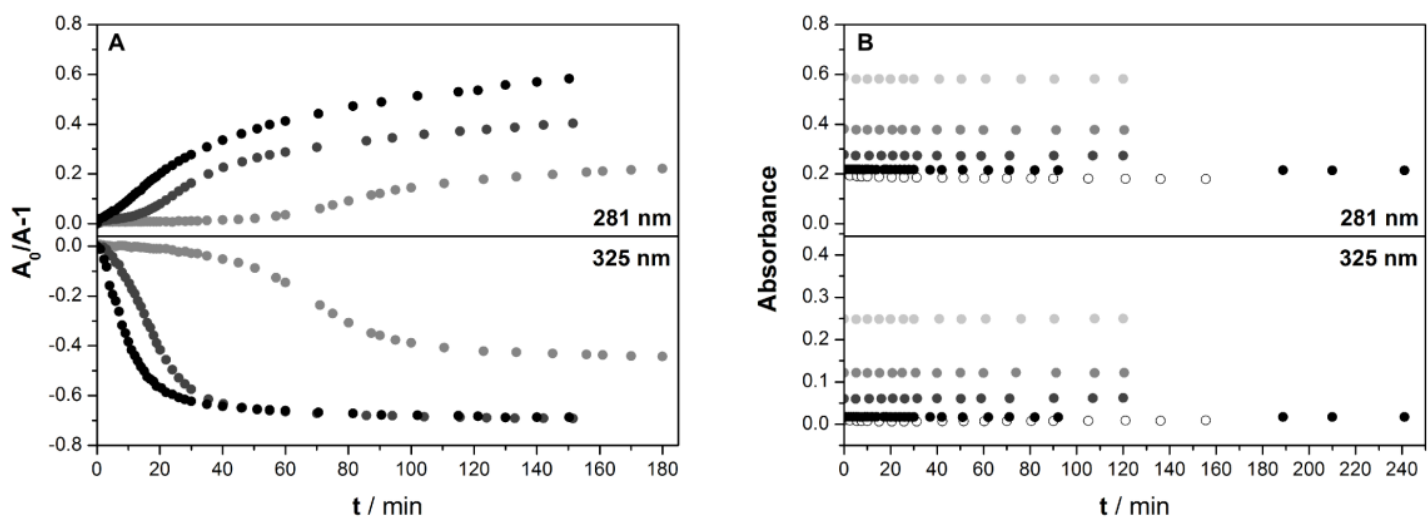

Figure 3/ Figura 3 - Licofelone absorbance variation at $281 \mathrm{~nm}$ (upper graph) and $325 \mathrm{~nm}$ (lower graph), at $\mathrm{pH}$ 5.0 (A) or 7.4 (B) as a function of time and DMPC concentration [0 (white), $100 \mu \mathrm{M}$ (black), $200 \mu \mathrm{M}$ (dark gray); $500 \mu \mathrm{M}$ (gray); $1000 \mu \mathrm{M}$ (light gray)]. To improve clarity, the absorbance variation is expressed as A0/A-1 for data at $\mathrm{pH} 5.0$ and as absorbance for results at $\mathrm{pH}$ 7.4./ Variação da absorvência do licofelone a $281 \mathrm{~nm}$ (painel superior) e a $325 \mathrm{~nm}$ (painel inferior) e a pH 5,0 (A) ou 7,4 (B) em função do tempo e da concentração de DMPC [0 $\mu \mathrm{M}$ (branco), $100 \mu \mathrm{M}$ (preto), $200 \mu \mathrm{M}$ (cinzento escuro); $500 \mu \mathrm{M}$ (cinzento); 1000 $\mu \mathrm{M}$ (cinzento claro)]. Para facilitar a leitura, a variação da absorvência está expressa como A0/A-1 para os dados a $\mathrm{pH}$ 5,0 e como absorvência para os resultados a $\mathrm{pH} 7,4$. 

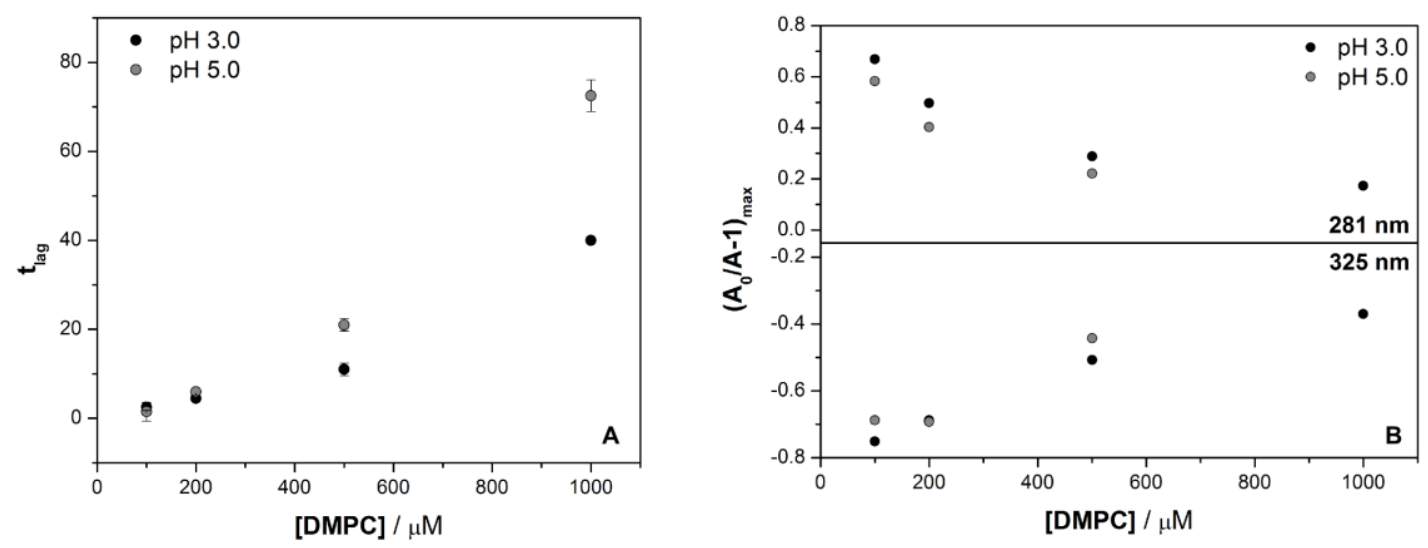

Figure 4/ Figura 4 - (A) Time-lag (tlag) before initiation of licofelone degradation as a function of DMPC concentration and $\mathrm{pH}$. (B) Maximum variation of licofelone absorbance, expressed as (A0/A-1)max, at $281 \mathrm{~nm}$ (upper graph) and $325 \mathrm{~nm}$ (lower graph) as a function of DMPC concentration and $\mathrm{pH} . /$ (A) Tempo de atraso (tlag) antes do início da degradação do licofelone em função da concentração de DMPC e do pH. (B) Variação máxima da absorvência do licofelone, expressa como (Â0/A-1)max, a $281 \mathrm{~nm}$ (painel superior) e a 325 $\mathrm{nm}$ (painel inferior) em função da concentração de DMPC e do $\mathrm{pH}$.

\section{Discussion}

Biological membranes play key roles in diverse physiological and pathophysiological processes. Studies on understanding their structure and function, as well as their interactions with biological substances and xenobiotics have been increasing more and more in the last decades (18-20). In the context of medicinal chemistry, the evaluation of drug-membrane interactions is a valuable approach to fully understand the mechanisms of action and toxicity of biologically-active compounds $(19,20)$. These studies are particularly relevant for anti-inflammatory drugs as their efficacy and toxicity seem to be directly related to the drugs interaction with membrane lipids and proteins $(11,14,21)$. Despite the information collected in the last decades, studies on drug-membrane interactions are often disregarded in drug discovery but they seem to be a promising strategy to improve the success rate of this laborious process, as previously suggested elsewhere $(22,23)$.

In this context, this study aimed at evaluating the interactions of a drug candidate (licofelone) with a membrane model made of a phosphatidylcholine (DMPC). In the first attempt to characterize these interactions, the data collected showed not only that licofelone is degraded in the presence of DMPC bilayers, but also that the rate and extent of degradation is dependent on $\mathrm{pH}$ and DMPC concentration.

Licofelone is an acidic drug and its $\mathrm{pH}$-dependent degradation may be related to the drug ionization states.

\section{Discussão}

As membranas biológicas desempenham um papel preponderante em diversos processos fisiológicos e patofisiológicos. Estudos quanto ao entendimento da sua estrutura e função, assim como das suas interações com substâncias biológicas e xenobióticos têm aumentado mais e mais nas últimas décadas (18-20). No contexto da química medicinal, a avaliação das interações fármaco-membrana é uma estratégia valiosa para descrever na totalidade o mecanismo de ação e de toxicidade de compostos bioativos $(19,20)$. Estes estudos são particularmente relevantes para fármacos anti-inflamatórios já que a sua eficácia e toxicidade parecem estar diretamente relacionadas com a interação destes fármacos com lípidos e proteínas membranares $(11,14,21)$. Apesar da informação recolhida nas últimas décadas, os estudos de interação fármaco-membrana são ainda regularmente desconsiderados durante o desenvolvimento de novos fármacos. No entanto, estes parecem constituir uma estratégia interessante a adotar para melhorar a taxa de sucesso deste longo processo, tal como se sugeriu anteriormente $(22,23)$.

Neste contexto, este trabalho tem como objetivo avaliar as interações de um fármaco em desenvolvimento (licofelone) com um modelo de membrana constituído por uma fosfatidilcolina (DMPC). Na primeira tentativa para caraterizar estas interações, os resultados obtidos demonstraram que o licofelone é degradado na presença de bicamadas de DMPC e que a velocidade e 
The acidity dissociation constant $\left(p K_{a}\right)$ of licofelone is 4.8 , according to MarvinSketch calculator (Chemaxon). Licofelone degradation was faster and more extensive at lower $\mathrm{pH}$ values, at which the protonated form of licofelone was present. In turn, no spectral changes were observed for at least two hours at $\mathrm{pH} 7.4$, at which the deprotonated and charged form of licofelone prevails. Therefore, it is conceivable that the neutral form of licofelone was the microspecies undergoing degradation. Licofelone degradation was also dependent on DMPC concentration. Interestingly, it was faster and in larger extent for lower DMPC concentrations. Predictions of the octanol:water $\log D\left(\log D_{\mathrm{O} / \mathrm{w}}\right)$ of licofelone suggested that this drug may have high affinity for phosphatidylcholine bilayers, since calculated $\log D_{\mathrm{O} / \mathrm{w}}$ was 5.72 , 5.32, and 3.15 for $\mathrm{pH} 3.0,5.0$, and 7.4 (respectively) according to MarvinSketch calculator (Chemaxon). Since licofelone seems to have higher affinity to lipid media than to aqueous phases, it is plausible that the drug will concentrate in phosphatidylcholine bilayers. The lower the DMPC concentration, the higher the local concentration of drug inside the phospholipid bilayers, which seems to favor the occurrence of licofelone degradation concerning both rapidity and efficacy. Thus, it is possible that more than one licofelone molecule must collide for the degradation to occur, justifying the slower rate and extent of licofelone degradation as DMPC concentration increases and licofelone becomes more diluted in the lipid phase. The DMPC bilayer may act as a catalyst not only by concentrating the drug molecule, but also by furnishing a favorable chemical environment for the degradation to occur.

One possible hypothesis for the degradation mechanism of licofelone may comprise the formation of anhydride dimers of licofelone, in a similar fashion as described for naphthalene-1,8-dicarboxylic acid and dialkylmaleic acids $(24,25)$. This seems to be a reasonable possibility for two main reasons: a) the unionized acid is the active species of anhydride formation (25) and the degradation of licofelone was favored at lower $\mathrm{pH}$; and b) the higher the local concentration of licofelone in DMPC bilayers (lower lipid concentration), the higher the probability of two carboxylic acids from two different licofelone molecules to collide, increasing the velocity and the extent of licofelone degradation, as observed herein. Further investigations are awaited to confirm the suggested mechanism by completing the structural elucidation of the products formed upon licofelone degradation.

As this is a biomimetic study, the overall complexity of the biological membranes is not considered in this work. Future work is warranted to verify if the li- a extensão da degradação é dependente do pH do meio e da concentração de DMPC.

O licofelone é um composto ácido e sua degradação dependente do $\mathrm{pH}$ pode estar relacionada com os seus estados de ionização. A constante de acidez $\left(p K_{a}\right)$ do licofelone é 4,8, de acordo com o cálculo efetuado no software MarvinSketch (Chemaxon). A degradação do licofelone foi mais rápida e em maior extensão para valores mais baixos de $\mathrm{pH}$, nos quais a forma protonada do licofelone estava presente. Por sua vez, não foram observadas alterações espectrais por pelo menos $2 \mathrm{~h}$ a $\mathrm{pH} 7,4$, valor de $\mathrm{pH}$ no qual prevalece a forma desprotonada e carregada do licofelone. Portanto, é concebível que a forma neutra do licofelone seja a microespécie a sofrer degradação.

Adicionalmente, a degradação do licofelone foi dependente da concentração de DMPC. Curiosamente, esta foi mais rápida e em maior extensão para concentrações mais baixas de DMPC. As previsões de $\log D$ no sistema octanol:água $\left(\log D_{\mathrm{O} / \mathrm{A}}\right)$ do licofelone sugeriram que este fármaco pode ter alta afinidade pelas bicamadas de fosfatidilcolina, uma vez que os valores calculados foram 5,72, 5,32 e 3,15 para $\mathrm{pH} 3,0,5,0$ e 7,4 (respetivamente), de acordo com o cálculo efetuado no software MarvinSketch (Chemaxon). Como o licofelone parece ter maior afinidade para o meio lipídico do que para a fase aquosa, é plausível que o fármaco se concentre nas bicamadas da fosfatidilcolina. Quanto menor a concentração de DMPC, maior a concentração local de fármaco nas bicamadas fosfolipídicas, o que parece favorecer a ocorrência da degradação do licofelone quanto à sua rapidez e eficácia. Assim, é possível que a degradação ocorra através da colisão de mais do que uma molécula de licofelone, justificando o facto da velocidade e a extensão da degradação serem mais lentas à medida que a concentração de DMPC aumenta e o licofelone se dilui na fase lipídica. Assim sendo, a bicamada de DMPC pode atuar como um catalisador, não apenas pelo aumento da concentração local do fármaco, mas também pela criação de um ambiente químico favorável para a degradação.

Uma hipótese possível para o mecanismo de degradação do licofelone poderá consistir na formação de dímeros anidrido do licofelone, de uma forma semelhante ao descrito para o ácido naftaleno-1,8-dicarboxílico e para os ácidos dialquilmaleico $(24,25)$. Esta parece ser uma hipótese provável por duas razões: a) o ácido protonado é a espécie ativa da formação de anidrido (25) e a degradação de licofelone foi favorecida a $\mathrm{pH}$ baixo; e b) quanto maior a concentração local de licofelone na bicamada de DMPC (concentração lipídica baixa), maior será a probabilidade de colisão de dois ácidos 
cofelone degradation occurs in the presence of other membrane lipids and membrane proteins by performing in vitro studies with more complex membrane models and with cell cultures.

Despite these limitations, this study highlights the importance of considering membrane lipids on the early stages of drug development. Beyond providing information about the drugs mode of action and toxicity mechanisms, as previously described for various antiinflammatory drugs $(11-14,21-23,26)$, this study also showed that the evaluation of drug-membrane interactions may also be useful to assess the stability of drug candidates in biologically-relevant media, avoiding setbacks in later stages of drug development.

\section{Conclusions}

The preliminary data regarding the characterization of licofelone-DMPC interactions is presented herein. To our knowledge, this is the first report on the $\mathrm{pH}$ sensitive degradation of licofelone in liposome:water systems. This information is particularly relevant if this drug is intended to be administered orally, as licofelone may undergo degradation in the stomach due to the acidic conditions of the gastric lumen. In the gastric mucosa, the presence of external phosphatidylcholine layers may even increase the rate and the extent of licofelone degradation. Thus, the licofelone administration in gastro-resistant formulations may be a useful way to avoid the drug degradation in vivo.

Although licofelone data seem to support the multiple target strategy to improve the anti-inflammatory therapy, a long journey is still ahead to fully characterize the impact of concomitantly inhibiting COX and 5-LOX in the in vivo eicosanoids biosynthesis, as well as its consequences in terms of toxicity, contraindications, and pharmacological interactions during the short and longterm therapy of inflammatory conditions.

Overall, this study contributes to this pathway by highlighting the urgency of considering lipids in drug development to further understand drugs stability in bio- carboxílicos provenientes de moléculas de licofelone diferentes, aumentando assim a velocidade e a extensão da degradação. O mecanismo de degradação do licofelone terá de ser confirmado no futuro através da elucidação estrutural dos produtos de degradação.

Como se trata de um estudo biomimético, a complexidade global das membranas biológicas não foi considerada neste trabalho. No futuro, será então necessário confirmar se a degradação do licofelone também ocorre na presença de outros lípidos e proteínas membranares pelo recurso a estudos in vitro com modelos de membrana mais complexos e pelo recurso a linhas celulares. Apesar destas limitações, este trabalho salienta a importância de considerar os lípidos membranares nas fases iniciais do desenvolvimento de novos fármacos. Para além de fornecer informação quanto aos mecanismos de ação e de toxicidade, tal como descrito para vários anti-inflamatórios (11-14,21-23,26), os estudos de interação fármaco-membrana também podem ser uma mais-valia para avaliar a estabilidade dos compostos em meios biologicamente relevantes. Desta forma, poderão constituir um meio para evitar contratempos nas fases mais avançadas do desenvolvimento de novos fármacos.

\section{Conclusões}

Os dados preliminares quanto à caracterização das interações licofelone-DMPC são apresentados neste trabalho. Segundo conseguimos apurar, este é a primeiro descrição da degradação sensível ao $\mathrm{pH}$ do licofelone em sistemas lipossoma:água. Esta informação é particularmente relevante no caso deste fármaco ser administrado por via oral, pois o licofelone pode sofrer degradação no estômago devido às condições ácidas do lúmen. Na mucosa gástrica, a presença de camadas externas de fosfatidilcolina pode ainda aumentar a velocidade e a extensão da degradação do licofelone. Assim, a administração de licofelone em formulações gastrorresistentes pode ser uma mais-valia para evitar a degradação do fármaco in vivo.

Apesar dos resultados obtidos com o licofelone suportarem a estratégia dos alvos múltiplos para melhorar a terapia anti-inflamatória, um longo caminho está ainda por percorrer para caracterizar na totalidade o impacto de inibir concomitantemente a COX e a 5-LOX na biossíntese de eicosanóides in vivo e para avaliar as suas consequências a nível da toxicidade, contraindicações e interações farmacológicas ao longo da terapia aguda e crónica das condições inflamatórias.

No geral, este trabalho consiste em mais um passo deste 
logically relevant media. The evaluation of drug-lipid interactions in the early stages of drug development may avoid important setbacks during clinical evaluation, decreasing the financial and biological costs of this process.

\section{Acknowledgements}

This work received financial support from: PT national funds (FCT/MCTES, Fundação para a Ciência e a Tecnologia and Ministério da Ciência, Tecnologia e Ensino Superior) [Grant: UID/QUI/50006/2019]; FCT (Fundação para a Ciência e a Tecnologia), POCH (Programa Operacional Capital Humano) and EU (European Union) [Grants: SFRH/BD/109621/2015 and IF/00293/2015]; CNPq (Conselho Nacional de Desenvolvimento Científico e Tecnológico) [Grants: 160446/2013-9 and Proc. 301250/2013-8]; FAPESP (Fundação de Amparo à Pesquisa do Estado de São Paulo) [Projeto Temático 2013/08166-5]; INCT-FCx (Instituto Nacional de Ciência e Tecnologia de Fluidos Complexos).

\section{Conflict of interests}

The authors declare that there is no financial or personal relationship that represents any potential conflict of interests. caminho, destacando a urgência de considerar os lipídios no desenvolvimento de novos fármacos para entender na totalidade a estabilidade dos compostos em meios biologicamente relevantes. A avaliação das interações fármaco-lípido nas fases iniciais do desenvolvimento de fármacos pode evitar transtornos importantes durante a fase clínica, diminuindo os custos financeiros e biológicos deste processo.

\section{Agradecimentos}

Agradece-se o apoio financeiro obtido através de: fundos nacionais portugueses (FCT/MCTES, Fundação para a Ciência e a Tecnologia e Ministério da Ciência, Tecnologia e Ensino Superior) [Financiamento: UID/ QUI/50006/2019]; FCT (Fundação para a Ciência e a Tecnologia), POCH (Programa Operacional Capital Humano) e UE (União Europeia) [Financiamento: SFRH/BD/109621/2015 e IF/00293/2015]; CNPq (Conselho Nacional de Desenvolvimento Científico e Tecnológico) [Financiamento: 160446/2013-9 e Proc. 301250/2013-8]; FAPESP (Fundação de Amparo à Pesquisa do Estado de São Paulo) [Projeto Temático 2013/08166-5]; INCT-FCx (Instituto Nacional de Ciência e Tecnologia de Fluidos Complexos).

\section{Conflitos de interesse}

Os autores declaram não existir nenhuma relação pessoal ou financeira que possa configurar uma situação de possível conflito de interesses. 


\section{References / Referências}

1. Pereira-Leite C, Nunes C, Jamal SK, Cuccovia IM, Reis S. Nonsteroidal Anti-Inflammatory Therapy: A Journey Toward Safety. Med Res Rev. 2017; 37(4):802-59.

2. Koeberle A, Siemoneit U, Buhring U, Northoff H, Laufer S, Albrecht W, et al. Licofelone suppresses prostaglandin E2 formation by interference with the inducible microsomal prostaglandin E2 synthase-1. J Pharmacol Exp Ther. 2008; 326(3):975-82.

3. Fischer L, Hornig M, Pergola C, Meindl N, Franke L, Tanrikulu Y, et al. The molecular mechanism of the inhibition by licofelone of the biosynthesis of 5-lipoxygenase products. Br J Pharmacol. 2007; 152(4):471-80.

4. Tries S, Neupert W, Laufer S. The mechanism of action of the new antiinflammatory compound ML3000: inhibition of 5-LOX and COX-1/2. Inflamm Res. 2002; 51(3):135-43.

5. Cicero AF, Laghi L. Activity and potential role of licofelone in the management of osteoarthritis. Clin Interv Aging. 2007; 2(1):73-9.

6. Tries S, Laufer S. The pharmacological profile of ML3000: A new pyrrolizine derivative inhibiting the enzymes cyclo-oxygenase and 5-lipoxygenase. Inflammopharmacology. 2001; 9(1):113-24.

7. Rotondo S, Dell'Elba G, Manarini S, Cerletti C, Evangelista V. The lipoxygenase-cyclooxygenase inhibitor licofelone prevents thromboxane A2-mediated cardiovascular derangement triggered by the inflammatory peptide fMLP in the rabbit. Eur J Pharmacol. 2006; 546(1-3):95-101.

8. Moreau M, Daminet S, Martel-Pelletier J, Fernandes J, Pelletier JP. Superiority of the gastroduodenal safety profile of licofelone over rofecoxib, a COX-2 selective inhibitor, in dogs. J Vet Pharmacol Ther. 2005; 28(1):81-6.

9. Wallace JL, Carter L, McKnight W, Tries S, Laufer S. ML 3000 reduces gastric prostaglandin synthesis without causing mucosal injury. Eur J Pharmacol. 1994; 271(2-3):525-31.

10. Kulkarni SK, Singh VP. Licofelone--a novel analgesic and anti-inflammatory agent. Curr Top Med Chem. 2007; 7(3):251-63.

11. Pereira-Leite $\mathrm{C}$, Nunes $\mathrm{C}$, Reis $\mathrm{S}$. Interaction of nonsteroidal anti-inflammatory drugs with membranes: In vitro assessment and relevance for their biological actions. Prog Lipid Res. 2013; 52(4):571-84.

12. Lichtenberger LM, Zhou Y, Jayaraman V, Doyen JR, O'Neil RG, Dial EJ, et al. Insight into NSAID-induced membrane alterations, pathogenesis and therapeutics: Characterization of interaction of NSAIDs with phosphatidylcholine. Biochim Biophys Acta, Mol Cell Biol Lipids. 2012; 1821(7):9941002 .

13. Pereira-Leite C, Nunes C, Grahl D, Bozelli JC, Schreier S, Kamma-Lorger CS, et al. Acemetacin-phosphatidylcholine interactions are determined by the drug ionization state. Phys Chem Chem Phys. 2018; 20(21):14398-409.

14. Manrique-Moreno M, Heinbockel L, Suwalsky M, Garidel P, Brandenburg K. Biophysical study of the non-steroidal anti-inflammatory drugs (NSAID) ibuprofen, naproxen and diclofenac with phosphatidylserine bilayer membranes. Biochim Biophys Acta. 2016; 1858(9):2123-31.

15. Nardone G, Laccetti P, Civiletti C, Budillon G. Phospholipid composition of human gastric mucosa: a study of endoscopic biopsy specimens. Gut. 1993; 34(4):456-60.

16. Bahari HM, Ross IN, Turnberg LA. Demonstration of a pH gradient across the mucus layer on the surface of human gastric mucosa in vitro. Gut. 1982; 23(6):513-6.

17. Magalhaes LM, Nunes C, Lucio M, Segundo MA, Reis S, Lima JLFC. High-throughput microplate assay for the determination of drug partition coefficients. Nat Protoc. 2010; 5(11):1823-30.

18. Casares D, Escribá PV, Rosselló CA. Membrane Lipid Composition: Effect on Membrane and Organelle Structure, Function and Compartmentalization and Therapeutic Avenues. Int J Mol Sci. 2019; 20(9):2167.

19. Lopes D, Jakobtorweihen S, Nunes C, Sarmento B, Reis S. Shedding light on the puzzle of drug-membrane interactions: Experimental techniques and molecular dynamics simulations. Prog Lipid Res. 2017; 65:24-44.

20. Lucio M, Lima JLFC, Reis S. Drug-Membrane Interactions: Significance for Medicinal Chemistry. Curr Med Chem. 2010; 17(17):1795-809.

21. Gaspar D, Lucio M, Rocha S, Lima JLFC, Reis S. Changes in PLA(2) activity after interacting with anti-inflammatory drugs and model membranes: evidence for the involvement of tryptophan residues. Chem Phys Lipids. 2011; 164(4):292-9.

22. Pereira-Leite C, Nunes C, Bozelli JC, Jr., Schreier S, Kamma-Lorger CS, Cuccovia IM, et al. Can NO-indomethacin counteract the topical gastric toxicity induced by indomethacin interactions with phospholipid bilayers? Colloids Surf B Biointerfaces. 2018; 169:375-83.

23. Pereira-Leite C, Lopes-de-Campos D, Fontaine P, Cuccovia IM, Nunes C, Reis S. Licofelone-DPPC Interactions: Putting Membrane Lipids on the Radar of Drug Development. Molecules. 2019; 24(3):516.

24. Barros TC, Yunes S, Menegon G, Nome F, Chaimovich H, Politi MJ, et al. Hydrolysis of 1,8- and 2,3-naphthalic anhydrides and the mechanism of cyclization of 1,8-naphthalic acid in aqueous solutions. J Chem Soc, Perkin Trans 2. 2001; (12):2342-50.

25. Eberson L, Welinder H. Cyclic anhydrides. III. Equilibrium constants for the acid-anhydride equilibrium in aqueous solutions of certain vicinal diacids. J Am Chem Soc. 1971; 93(22):5821-6.

26. Pereira-Leite C, Nunes C, Lima JL, Reis S, Lucio M. Interaction of Celecoxib with Membranes: The Role of Membrane Biophysics on its Therapeutic and Toxic Effects. J Phys Chem B. 2012; 116(46):13608-17. 